Article

\title{
Anti-Inflammatory Cembranoids from a Formosa Soft Coral Sarcophyton cherbonnieri
}

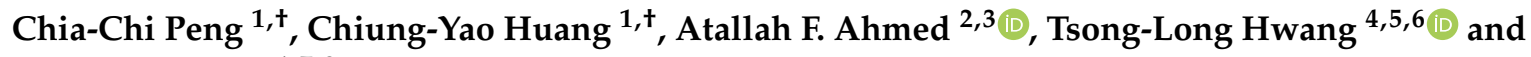 \\ Jyh-Horng Sheu $1,7,8, *$ \\ 1 Department of Marine Biotechnology and Resources, National Sun Yat-sen University, Kaohsiung 804, \\ Taiwan; Chia-Chi.Peng@hki-jena.de (C.-C.P.); huangcy@mail.nsysu.edu.tw (C.-Y.H.) \\ 2 Department of Pharmacognosy, College of Pharmacy, King Saud University, Riyadh 11451, Saudi Arabia; \\ afahmed@ksu.edu.sa \\ 3 Department of Pharmacognosy, Faculty of Pharmacy, Mansoura University, Mansoura 35516, Egypt \\ 4 Graduate Institute of Natural Products, College of Medicine, Chang Gung University, Taoyuan 333, Taiwan; \\ htl@mail.cgu.edu.tw \\ 5 Research Center for Industry of Human Ecology and Graduate Institute of Health Industry Technology, \\ Chang Gung University of Science and Technology, Taoyuan 333, Taiwan \\ 6 Department of Anesthesiology, Chang Gung Memorial Hospital, Taoyuan 333, Taiwan \\ 7 Graduate Institute of Natural Products, Kaohsiung Medical University, Kaohsiung 807, Taiwan \\ 8 Department of Medical Research, China Medical University Hospital, China Medical University, \\ Taichung 404, Taiwan \\ * Correspondence: sheu@mail.nsysu.edu.tw; Tel.: +886-7-525-2000 (ext. 5030); Fax: +886-7-525-5020 \\ + These authors contributed equally to this work.
}

Received: 25 September 2020; Accepted: 13 November 2020; Published: 19 November 2020

\begin{abstract}
The present investigation on chemical constituents of the soft coral Sarcophyton cherbonnieri resulted in the isolation of seven new cembranoids, cherbonolides F-L (1-7). The chemical structures of 1-7 were determined by spectroscopic methods, including infrared, one- and two-dimensional (1D and 2D) NMR (COSY, HSQC, HMBC, and NOESY), MS experiments, and a chemical reduction of hydroperoxide by triphenylphosphine. The anti-inflammatory activities of 1-7 against neutrophil proinflammatory responses were evaluated by measuring their inhibitory ability toward $\mathrm{N}$-formyl-methionyl-leucyl-phenylalanine/cytochalasin B (fMLF/CB)-induced superoxide anion generation and elastase release in primary human neutrophils. The results showed that all isolates exhibited moderate activities, while cherbonolide G (2) and cherbonolide H (3) displayed a more active effect than others on the inhibition of elastase release $(48.2 \% \pm 6.2 \%)$ and superoxide anion generation $(44.5 \% \pm 4.6 \%)$ at $30 \mu \mathrm{M}$, respectively.
\end{abstract}

Keywords: Sarcophyton cherbonnieri; cembranoid; anti-inflammatory activity; elastase release; superoxide anion generation

\section{Introduction}

Series of cembranoidal secondary metabolites from soft corals have been shown to exhibit attractive biological activities including cytotoxicity [1-14] and anti-inflammatory ability $[6,7,9,11$, 13-18]. From previous investigations of exploring bioactive natural products from soft corals, many cembranoids were discovered from organisms of the genera Sarcophyton, [1-8,16], Sinularia [9-12,17,18], and Lobophyton [13-15]. In some cases, two cembranoid units could be linked to produce biscembranoids via various reactions [18-24], marking the high diversity and complexity in chemical structures of cembrane-related soft coral natural products. 
Many studies have revealed that soft corals of the genus Sarcophyton are important sources of various types of natural products, some of them with notable bioactivies [25-28]. Our previous chemical study on Sarcophyton cherbonnieri led to the isolation of six new cembranoids cherbonolides A-E and one biscembranoid bischerbolide peroxide, along with a known compound, isosarcophine [24]. In continuation of our effort on discovery of new and bioactive compounds from marine animals, we further explored the chemical constituents of $S$. cherbonnieri. This investigation again led to the discovery of new cembranoids, cherbonolides F-L (1-7). The structures of 1-7 (Figure 1) were determined by spectroscopic analysis, including two-dimensional (2D) NMR experiments and a chemical reaction. Compounds 2 and 4 were elucidated as cembranoids possessing an allylic peroxy group. Cembranoids of isosarcophine-type have been reported frequently [24,27-30].

The screening of the in vitro anti-inflammatory activities through the inhibition of superoxide anion generation and elastase release in $N$-formyl-methionyl-leucyl-phenylalanine/cytochalasin B (fMLF/CB)-induced primary human neutrophils was also performed in order to unveil the anti-inflammatory ability of these compounds. We report herein the isolation, structure determination, and bioactivity of the new metabolites 1-7.

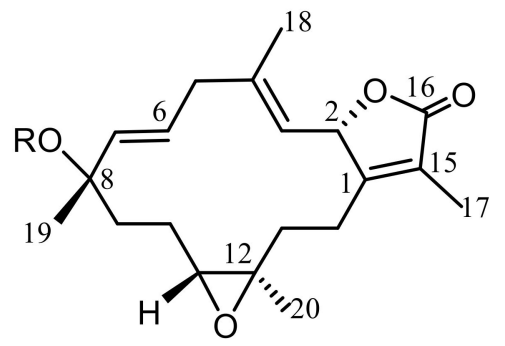

$1 \mathrm{R}=\mathrm{H}$ $2 \mathrm{R}=\mathrm{OH}$

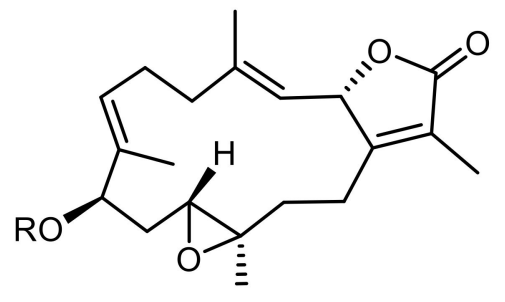

$3 \mathrm{R}=\mathrm{H}$

$4 \mathrm{R}=\mathrm{OH}$

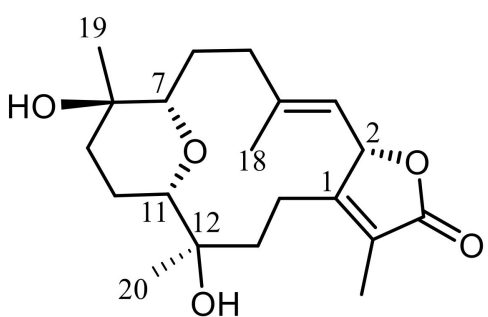

5

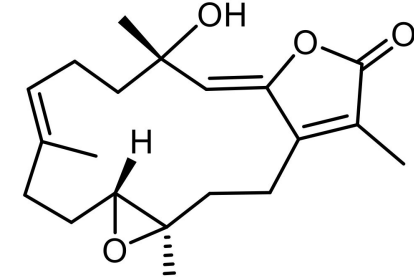

6

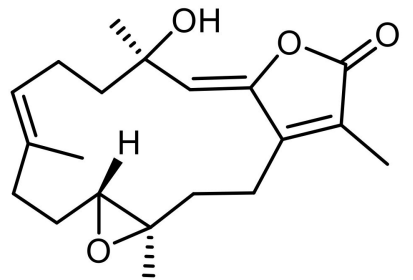

7

Figure 1. New cembranoids isolated from Sarcophyton cherbonnieri.

\section{Results and Discussion}

Solvent-free residue of the ethyl acetate extract of the soft coral S. cherbonnieri was separated and further purified by chromatographic methods to yield metabolites 1-7. The structures were established by extensive analyses of MS and NMR spectra (Figures S1-S49, Supplementary Materials). ${ }^{13} \mathrm{C}-$ and ${ }^{1} \mathrm{H}-\mathrm{NMR}$ data which were essential for structure determination of 1-7 are listed in Tables 1-3.

Cherbonolide F (1) was obtained as a colorless oil. The molecular formula of $\mathbf{1}, \mathrm{C}_{20} \mathrm{H}_{28} \mathrm{O}_{4}$, was established by high-resolution electrospray ionization mass spectrometry (HR-ESI-MS) $(\mathrm{m} / \mathrm{z}$ calculated 355.1880; found 355.1879, $\left[\mathrm{M}+\mathrm{Na}^{+}\right)$, implying seven degrees of unsaturation. The IR spectrum of 1 revealed the absorptions of a hydroxy $\left(v_{\max } 3460 \mathrm{~cm}^{-1}\right)$ and a lactonic carbonyl group $\left(v_{\max } 1748 \mathrm{~cm}^{-1}\right)$. The ${ }^{13} \mathrm{C}-\mathrm{NMR}$ spectrum of $\mathbf{1}$ showed 20 signals which were assigned to four methyls, five $s p^{3}$ methylenes, two $s p^{3}$ oxygenated methines, three $s p^{2}$ methines, and two $s p^{3}$ and four $s p^{2}$ nonprotonated carbon atoms (Table 1) with the assistance of distortionless enhancement by polarization transfer (DEPT) spectra. Carbon signals resonating at $\delta_{\mathrm{C}} 173.9(\mathrm{C}), 160.5(\mathrm{C}), 123.6(\mathrm{C})$, $78.6(\mathrm{CH})$, and $9.0\left(\mathrm{CH}_{3}\right)$ and proton signals resonating at $\delta_{\mathrm{H}} 4.95(1 \mathrm{H}, \mathrm{dd}, J=10.0,1.6 \mathrm{~Hz})$ and $\delta_{\mathrm{H}}$ 
$1.66(3 \mathrm{H}, \mathrm{s})$ were attributed to signals of an $\alpha$-methyl- $\alpha, \beta$-unsaturated- $\gamma$-lactone ring by comparing the NMR data of the $\gamma$-lactone ring of the known compound isosarcophine (7). Signals at $\delta_{C} 61.2$ $(\mathrm{CH}), 60.2(\mathrm{C})$, and $\delta_{\mathrm{H}} 2.54(1 \mathrm{H}, \mathrm{dd}, J=6.0,6.0 \mathrm{~Hz})$ showed the appearance of a trisubstituted epoxide. One trisubstituted and one disubstituted double bond were identified by NMR signals resonating at $\delta_{\mathrm{C}} 120.9(\mathrm{CH}), 142.4(\mathrm{C})$ and $\delta_{\mathrm{H}} 4.54(1 \mathrm{H}, \mathrm{dd}, J=10.0,0.8 \mathrm{~Hz})$, and at $\delta_{\mathrm{C}} 140.3(\mathrm{CH}), 124.5(\mathrm{CH})$ and $\delta_{\mathrm{H}} 5.32(1 \mathrm{H}, \mathrm{d}, J=16.0 \mathrm{~Hz})$ and $5.38(1 \mathrm{H}, \mathrm{ddd}, J=16.0,6.8,6.8 \mathrm{~Hz})$, respectively. ${ }^{1} \mathrm{H}-{ }^{1} \mathrm{H}$ correlation spectroscopy (COSY) correlations established four separate proton sequences, which were connected by heteronuclear multiple bond correlation (HMBC) correlations (Figure 2). Essential HMBC correlations from $\mathrm{H}-2$ to $\mathrm{C}-1$ and $\mathrm{C}-4, \mathrm{H}_{2}-14$ to $\mathrm{C}-1$ and $\mathrm{C}-2, \mathrm{H}_{3}-17$ to $\mathrm{C}-1, \mathrm{C}-15$, and C-16, $\mathrm{H}_{3}-18$ to C-3, C-4, and C-5, $\mathrm{H}_{3}-19$ to $\mathrm{C}-7, \mathrm{C}-8$, and $\mathrm{C}-9$, and $\mathrm{H}_{3}-20$ to $\mathrm{C}-11, \mathrm{C}-12$, and $\mathrm{C}-13$ established the 14-membered ring carbon skeleton of $\mathbf{1}$, which also indicated the presence of a hydroxyl at C-8.

Furthermore, analysis of nuclear Overhauser effect (NOE) correlations was applied to establish the relative configuration of $\mathbf{1}$, as shown in Figure 3. It was revealed that H-2 showed NOE correlation with $\mathrm{H}_{3}-18$, but not with $\mathrm{H}-3$; therefore, assuming the $\beta$-orientation of $\mathrm{H}-2, \mathrm{H}_{3}-18$ should be located on the $\beta$ face. Moreover, $\mathrm{H}_{3}-18$ exhibited NOE correlation with $\mathrm{H}-7$, but not with $\mathrm{H}-6$, revealing the $\beta$-orientation of H-7 and the $\alpha$-orientation of H-6. Both H-6 and H-7 exhibited NOE interactions with $\mathrm{H}_{3}-19$, thus established the $\beta$-orientation of $\mathrm{H}_{3}-19$ as shown in Figure 3 . One methylene proton at C-13 exhibited NOE correlation with $\mathrm{H}-2$ and was characterized as $\mathrm{H}-13 \beta\left(\delta_{\mathrm{H}} 0.99, \mathrm{~m}\right)$, while the other proton was assigned as $\mathrm{H}-13 \alpha\left(\delta_{\mathrm{H}} 1.49, \mathrm{~m}\right)$. NOE correlations of H-13 $\beta$ with $\mathrm{H}-11$ and $\mathrm{H}-13 \alpha$ with $\mathrm{H}_{3}-20$ reflected the $\beta$-orientation of $\mathrm{H}-11$ and the $\alpha$-orientation of $\mathrm{H}_{3}-20$. The $E$ geometries of the trisubstituted C-3/C-4 and C-6/C-7 double bonds were also assigned from the NOE correlations of $\mathrm{H}_{3}-18$ $\left(\delta_{\mathrm{H}} 1.35\right.$, s) with $\mathrm{H}-2$, but not with $\mathrm{H}-3$, as well as the large coupling constant $J=16.0 \mathrm{~Hz}$ between $\mathrm{H}-6$ and H-7, and the observed more shielded signal of C-18 $\left(\delta_{C} 16.7\right)$. According to the above observations, the relative configuration of this compound was established. As $\mathbf{1}$ was isolated together with the previous reported compounds isosarcophine and cherbonolides A-E [24] from the same organism, it should possess the same $(2 S, 8 S, 11 R, 12 R)$-configuration from the shared biosynthetic pathway.

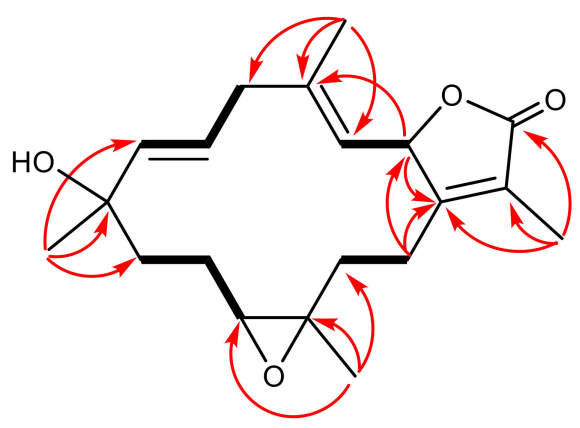

1

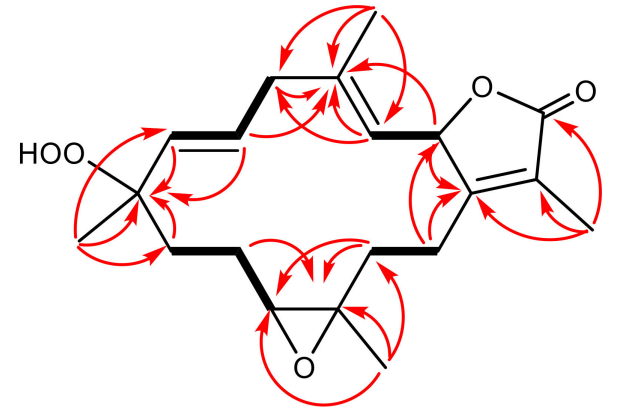

2

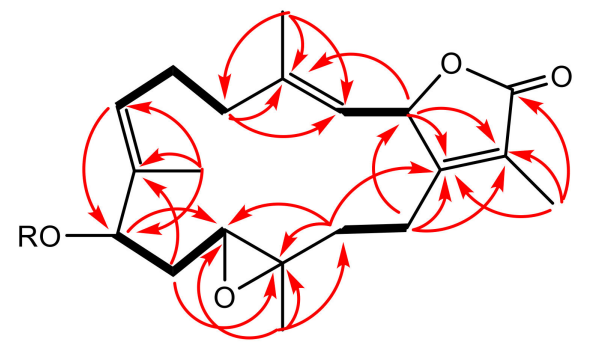

3: $\mathbf{R}=\mathbf{H}$

4: $\mathrm{R}=\mathrm{OH}$

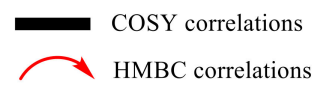

HMBC correlations

Figure 2. The selected COSY and HMBC correlations of 1-4. 
Table 1. ${ }^{13} \mathrm{C}-\mathrm{NMR}$ spectroscopic data of compounds 1-7.

\begin{tabular}{|c|c|c|c|c|c|c|c|}
\hline Position & $1^{a}$ & $2^{a}$ & $3^{a}$ & $4^{c}$ & $5^{a}$ & $6^{d}$ & $7^{d}$ \\
\hline 1 & $160.5(\mathrm{C})$ & $160.4(\mathrm{C})$ & $159.9(\mathrm{C})$ & $160.2(\mathrm{C})$ & $162.4(\mathrm{C})$ & $151.2(\mathrm{C})$ & $151.2(\mathrm{C})$ \\
\hline 2 & $78.6(\mathrm{CH})^{b}$ & $78.5(\mathrm{CH})$ & $77.7(\mathrm{CH})$ & $78.0(\mathrm{CH})$ & $79.5(\mathrm{CH})$ & $147.2(\mathrm{C})$ & $147.2(\mathrm{C})$ \\
\hline 3 & $120.9(\mathrm{CH})$ & $121.2(\mathrm{CH})$ & $121.8(\mathrm{CH})$ & $122.3(\mathrm{CH})$ & $120.7(\mathrm{CH})$ & $116.2(\mathrm{CH})$ & $116.1(\mathrm{CH})$ \\
\hline 4 & $142.4(\mathrm{C})$ & $142.1(\mathrm{C})$ & $143.2(\mathrm{C})$ & $143.4(\mathrm{C})$ & $143.2(\mathrm{C})$ & $72.7(\mathrm{C})$ & $72.6(\mathrm{C})$ \\
\hline 5 & $41.5\left(\mathrm{CH}_{2}\right)$ & $41.9\left(\mathrm{CH}_{2}\right)$ & $38.4\left(\mathrm{CH}_{2}\right)$ & $38.7\left(\mathrm{CH}_{2}\right)$ & $36.4\left(\mathrm{CH}_{2}\right)$ & $42.5\left(\mathrm{CH}_{2}\right)$ & $42.2\left(\mathrm{CH}_{2}\right)$ \\
\hline 6 & $124.5(\mathrm{CH})$ & $128.6(\mathrm{CH})$ & $23.9\left(\mathrm{CH}_{2}\right)$ & $24.4\left(\mathrm{CH}_{2}\right)$ & $24.7\left(\mathrm{CH}_{2}\right)$ & $23.1\left(\mathrm{CH}_{2}\right)$ & $23.2\left(\mathrm{CH}_{2}\right)$ \\
\hline 7 & $140.3(\mathrm{CH})$ & $135.9(\mathrm{CH})$ & $127.3(\mathrm{CH})$ & $130.9(\mathrm{CH})$ & $84.1(\mathrm{CH})$ & $127.2(\mathrm{CH})$ & $126.5(\mathrm{CH})$ \\
\hline 8 & $71.7(\mathrm{C})$ & $83.7(\mathrm{C})$ & $137.1(\mathrm{C})$ & $133.8(\mathrm{C})$ & $69.4(\mathrm{C})$ & $133.9(\mathrm{C})$ & $133.8(\mathrm{C})$ \\
\hline 9 & $39.7\left(\mathrm{CH}_{2}\right)$ & $35.7\left(\mathrm{CH}_{2}\right)$ & $76.2(\mathrm{CH})$ & $88.9(\mathrm{CH})$ & $40.7\left(\mathrm{CH}_{2}\right)$ & $36.3\left(\mathrm{CH}_{2}\right)$ & $36.2\left(\mathrm{CH}_{2}\right)$ \\
\hline 10 & $24.3\left(\mathrm{CH}_{2}\right)$ & $24.2\left(\mathrm{CH}_{2}\right)$ & $32.4\left(\mathrm{CH}_{2}\right)$ & $28.4\left(\mathrm{CH}_{2}\right)$ & $23.5\left(\mathrm{CH}_{2}\right)$ & $24.4\left(\mathrm{CH}_{2}\right)$ & $24.3\left(\mathrm{CH}_{2}\right)$ \\
\hline 11 & $61.3(\mathrm{CH})$ & $61.1(\mathrm{CH})$ & $59.2(\mathrm{CH})$ & $59.4(\mathrm{CH})$ & $80.1(\mathrm{CH})$ & $60.5(\mathrm{CH})$ & $60.5(\mathrm{CH})$ \\
\hline 12 & $60.2(\mathrm{C})$ & $60.2(\mathrm{C})$ & $60.1(\mathrm{C})$ & $60.6(\mathrm{C})$ & $72.6(\mathrm{C})$ & $60.2(\mathrm{C})$ & $60.3(\mathrm{C})$ \\
\hline 13 & $35.7\left(\mathrm{CH}_{2}\right)$ & $35.6\left(\mathrm{CH}_{2}\right)$ & $36.9\left(\mathrm{CH}_{2}\right)$ & $37.3\left(\mathrm{CH}_{2}\right)$ & $37.2\left(\mathrm{CH}_{2}\right)$ & $35.1\left(\mathrm{CH}_{2}\right)$ & $35.1\left(\mathrm{CH}_{2}\right)$ \\
\hline 14 & $23.2\left(\mathrm{CH}_{2}\right)$ & $22.9\left(\mathrm{CH}_{2}\right)$ & $23.6\left(\mathrm{CH}_{2}\right)$ & $24.0\left(\mathrm{CH}_{2}\right)$ & $20.2\left(\mathrm{CH}_{2}\right)$ & $19.6\left(\mathrm{CH}_{2}\right)$ & $19.8\left(\mathrm{CH}_{2}\right)$ \\
\hline 15 & $123.6(\mathrm{C})$ & $123.6(\mathrm{C})$ & $123.7(\mathrm{C})$ & $124.1(\mathrm{C})$ & $123.4(\mathrm{C})$ & $123.6(\mathrm{C})$ & $123.7(\mathrm{C})$ \\
\hline 16 & $173.9(\mathrm{C})$ & $173.9(\mathrm{C})$ & $173.8(\mathrm{C})$ & $174.2(\mathrm{C})$ & $174.4(\mathrm{C})$ & $169.5(\mathrm{C})$ & $169.8(\mathrm{C})$ \\
\hline 17 & $9.0\left(\mathrm{CH}_{3}\right)$ & $8.9\left(\mathrm{CH}_{3}\right)$ & $8.7\left(\mathrm{CH}_{3}\right)$ & $9.1\left(\mathrm{CH}_{3}\right)$ & $8.9\left(\mathrm{CH}_{3}\right)$ & $9.1\left(\mathrm{CH}_{3}\right)$ & $9.0\left(\mathrm{CH}_{3}\right)$ \\
\hline 18 & $16.7\left(\mathrm{CH}_{3}\right)$ & $16.2\left(\mathrm{CH}_{3}\right)$ & $14.4\left(\mathrm{CH}_{3}\right)$ & $14.7\left(\mathrm{CH}_{3}\right)$ & $16.2\left(\mathrm{CH}_{3}\right)$ & $29.9\left(\mathrm{CH}_{3}\right)$ & $29.4\left(\mathrm{CH}_{3}\right)$ \\
\hline 19 & $28.0\left(\mathrm{CH}_{3}\right)$ & $21.6\left(\mathrm{CH}_{3}\right)$ & $9.6\left(\mathrm{CH}_{3}\right)$ & $10.3\left(\mathrm{CH}_{3}\right)$ & $20.4\left(\mathrm{CH}_{3}\right)$ & $15.3\left(\mathrm{CH}_{3}\right)$ & $15.5\left(\mathrm{CH}_{3}\right)$ \\
\hline 20 & $16.7\left(\mathrm{CH}_{3}\right)$ & $16.9\left(\mathrm{CH}_{3}\right)$ & $16.0\left(\mathrm{CH}_{3}\right)$ & $16.2\left(\mathrm{CH}_{3}\right)$ & $23.7\left(\mathrm{CH}_{3}\right)$ & $17.5\left(\mathrm{CH}_{3}\right)$ & $17.4\left(\mathrm{CH}_{3}\right)$ \\
\hline
\end{tabular}

${ }^{\text {a }}$ Spectra recorded in $\mathrm{C}_{6} \mathrm{D}_{6}$ at $100 \mathrm{MHz}$ at $25^{\circ} \mathrm{C} .{ }^{\mathrm{b}}$ Attached protons were deduced by distortionless enhancement by polarization transfer (DEPT) experiments. ${ }^{c}$ Spectra recorded in $\mathrm{C}_{6} \mathrm{D}_{6}$ at $125 \mathrm{MHz}$. ${ }^{\mathrm{d}}$ Spectra recorded in $\mathrm{CDCl}_{3}$ at $100 \mathrm{MHz}$.

Table 2. ${ }^{1} \mathrm{H}-\mathrm{NMR}$ spectral data for compounds 1-4.

\begin{tabular}{ccccc}
\hline Position & $\mathbf{1}^{\mathbf{a}}$ & $\mathbf{2}^{\mathbf{a}}$ & $\mathbf{3}^{\mathbf{a}}$ & $\mathbf{4}^{\mathbf{b}}$ \\
\hline $\mathbf{2}$ & $4.95, \mathrm{dd}(10.0,1.6)^{\mathrm{c}}$ & $4.92, \mathrm{dd}(10.0,1.6)$ & $4.99, \mathrm{dd}(10.4,1.6)$ & $4.96, \mathrm{~d}(10.5)$ \\
$\mathbf{3}$ & $4.54, \mathrm{dd}(10.0,0.8)$ & $4.47, \mathrm{~d}(10.0)$ & $4.49, \mathrm{~d}(10.4)$ & $4.47, \mathrm{~d}(10.5)$ \\
$\mathbf{5}$ & $2.40, \mathrm{dd}(13.2,6.8)$ & $2.41, \mathrm{dd}(13.6,7.2)$ & $1.84, \mathrm{dd}(13.2,4.4)$ & $1.80, \mathrm{dd}(13.5,4.5)$ \\
& $2.26, \mathrm{dd}(13.2,6.8)$ & $2.27, \mathrm{dd}(13.6,7.2)$ & $1.92, \mathrm{~m}$ & $1.91, \mathrm{~m}$ \\
$\mathbf{6}$ & $5.38, \mathrm{ddd}(16.0,6.8,6.8)$ & $5.47, \mathrm{ddd}(16.8,7.2,7.2)$ & $1.73, \mathrm{~m}$ & $1.75, \mathrm{~m}$ \\
& & & $2.03, \mathrm{~m}$ & $2.02, \mathrm{~m}$ \\
$\mathbf{7}$ & $5.32, \mathrm{~d}(16.0)$ & $5.35, \mathrm{~d}(16.8)$ & $4.74, \mathrm{dd}(10.0,1.2)$ & $4.91, \mathrm{~d}(9.5)$ \\
$\mathbf{9}$ & $1.52, \mathrm{~m}$ & $1.57, \mathrm{~m}$ & $3.68, \mathrm{dd}(11.6,4.0)$ & $4.06, \mathrm{dd}(12.0,4.0)$ \\
& $1.59, \mathrm{~m}$ & $1.59, \mathrm{~m}$ & & \\
$\mathbf{1 0}$ & $1.43, \mathrm{~m}$ & $1.56, \mathrm{~m}$ & $1.47, \mathrm{~m}$ & $1.53, \mathrm{~m}$ \\
& $1.71, \mathrm{~m}$ & $1.56, \mathrm{~m}$ & $2.16, \mathrm{ddd}$ & $2.03, \mathrm{~m}$ \\
$\mathbf{1 1}$ & $2.54, \mathrm{dd}(6.0,6.0)$ & $2.44, \mathrm{dd}(6.4,6.4)$ & $2.03, \mathrm{~m}$ & $2.09, \mathrm{dd}(10.5,3.0)$ \\
$\mathbf{1 3}$ & $1.49, \mathrm{~m}$ & $1.69, \mathrm{~m}$ & $1.59, \mathrm{dd}(13.2,5.6)$ & $1.56, \mathrm{~m}$ \\
& $0.99, \mathrm{~m}$ & $0.99, \mathrm{~m}$ & $0.72, \mathrm{ddd}(13.2,13.2,2.8)$ & $0.69, \mathrm{dd}(13.5,13.5,2.5)$ \\
$\mathbf{1 4}$ & $1.81, \mathrm{~m}$ & $1.78, \mathrm{~m}$ & $1.93, \mathrm{~m}$ & $1.89, \mathrm{~m}$ \\
& $1.67, \mathrm{~m}$ & $1.68, \mathrm{~m}$ & $1.49, \mathrm{~m}$ & $1.43, \mathrm{~m}$ \\
$\mathbf{1 7}$ & $1.66, \mathrm{~s}$ & $1.66, \mathrm{~s}$ & $1.65, \mathrm{~s}$ & $1.65, \mathrm{~s}$ \\
$\mathbf{1 8}$ & $1.35, \mathrm{~s}$ & $1.29, \mathrm{~s}$ & $1.13, \mathrm{~s}$ & $1.11, \mathrm{~s}$ \\
$\mathbf{1 9}$ & $1.05, \mathrm{~s}$ & $1.19, \mathrm{~s}$ & $1.37, \mathrm{~s}$ & $1.37, \mathrm{~s}$ \\
$\mathbf{2 0}$ & $1.03, \mathrm{~s}$ & $1.02, \mathrm{~s}$ & $1.03, \mathrm{~s}$ & $1.01, \mathrm{~s}$ \\
\hline
\end{tabular}

${ }^{\text {a }}$ Spectra recorded in $\mathrm{C}_{6} \mathrm{D}_{6}$ at $400 \mathrm{MHz}$ at $25{ }^{\circ} \mathrm{C} .{ }^{\mathrm{b}}$ Spectra recorded in $\mathrm{C}_{6} \mathrm{D}_{6}$ at $500 \mathrm{MHz}$ at $25{ }^{\circ} \mathrm{C} .{ }^{\mathrm{c}}$ Coupling constants ( $J$ values) in $\mathrm{Hz}$ are shown in parentheses. 
Table 3. ${ }^{1} \mathrm{H}-\mathrm{NMR}$ spectral data for compounds 5-7.

\begin{tabular}{cccc}
\hline Position & $5^{\mathbf{a}}$ & $\mathbf{6}^{\mathbf{b}}$ & $\mathbf{7}^{\mathbf{b}}$ \\
\hline $\mathbf{2}$ & $4.92, \mathrm{~d}(11.2)^{\mathrm{c}}$ & & \\
$\mathbf{3}$ & $4.85, \mathrm{~d}(11.2)$ & $5.50, \mathrm{~s}$ & $5.52, \mathrm{~s}$ \\
$\mathbf{5}$ & $2.07, \mathrm{~m}$ & $1.83, \mathrm{~m}$ & $1.94, \mathrm{~m}$ \\
& $1.93, \mathrm{~m}$ & $1.98, \mathrm{~m}$ & $1.94, \mathrm{~m}$ \\
$\mathbf{6}$ & $1.31, \mathrm{~m}$ & $2.41, \mathrm{~m}$ & $2.46, \mathrm{~m}$ \\
& $1.70, \mathrm{~m}$ & $2.21, \mathrm{~m}$ & $2.14, \mathrm{~m}$ \\
$\mathbf{7}$ & $2.79, \mathrm{dd}(10.0,2.4)$ & $5.26, \mathrm{dd}(6.0,6.0)$ & $5.25, \mathrm{dd}(7.2,7.2)$ \\
$\mathbf{9}$ & $1.59, \mathrm{~m}$ & $2.28, \mathrm{~m}$ & $2.26, \mathrm{~m}$ \\
& $1.31, \mathrm{~m}$ & $2.08, \mathrm{~m}$ & $2.06, \mathrm{~m}$ \\
$\mathbf{1 0}$ & $1.22, \mathrm{~m}$ & $1.53, \mathrm{~m}$ & $1.54, \mathrm{~m}$ \\
& $1.50, \mathrm{~m}$ & $1.85, \mathrm{~m}$ & $1.86, \mathrm{~m}$ \\
$\mathbf{1 1}$ & $2.96, \mathrm{~d}(11.2)$ & $2.71, \mathrm{dd}(6.8,5.6)$ & $2.73, \mathrm{dd}(7.6,4.6)$ \\
$\mathbf{1 3}$ & $1.59, \mathrm{~m}$ & $2.16, \mathrm{~m}$ & $2.19, \mathrm{~m}$ \\
& $1.21, \mathrm{~m}$ & $1.63, \mathrm{~m}$ & $1.62, \mathrm{~m}$ \\
$\mathbf{1 4}$ & $2.16, \mathrm{ddd}(12.4,12.4,6.4)$ & $2.26, \mathrm{~m}$ & $2.24, \mathrm{~m}$ \\
& $1.59, \mathrm{~m}$ & $2.42, \mathrm{~m}$ & $2.45, \mathrm{~m}$ \\
$\mathbf{1 7}$ & $1.72, \mathrm{~s}$ & $1.95, \mathrm{~s}$ & $1.92, \mathrm{~s}$ \\
$\mathbf{1 8}$ & $1.47, \mathrm{~s}$ & $1.41, \mathrm{~s}$ & $1.51, \mathrm{~s}$ \\
$\mathbf{1 9}$ & $0.94, \mathrm{~s}$ & $1.66, \mathrm{~s}$ & $1.65, \mathrm{~s}$ \\
$\mathbf{2 0}$ & $0.89, \mathrm{~s}$ & $1.30, \mathrm{~s}$ & $1.28, \mathrm{~s}$ \\
\hline
\end{tabular}

${ }^{\text {a }}$ Spectra recorded in $\mathrm{C}_{6} \mathrm{D}_{6}$ at $400 \mathrm{MHz}$ at $25^{\circ} \mathrm{C}$. ${ }^{\mathrm{b}}$ Spectra recorded in $\mathrm{CDCl}_{3}$ at $400 \mathrm{MHz}$ at $25^{\circ} \mathrm{C}$. ${ }^{\mathrm{c}}$ Coupling constants ( $J$ values) in $\mathrm{Hz}$ are shown in parentheses.

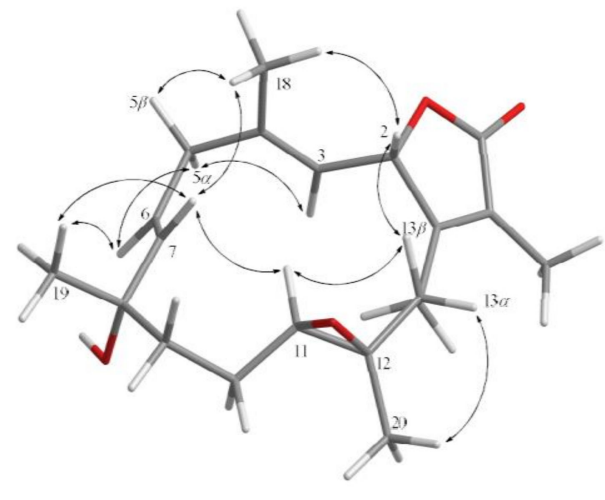

1

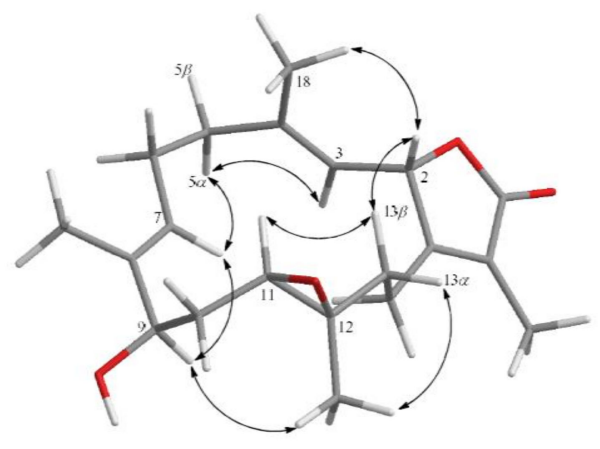

3

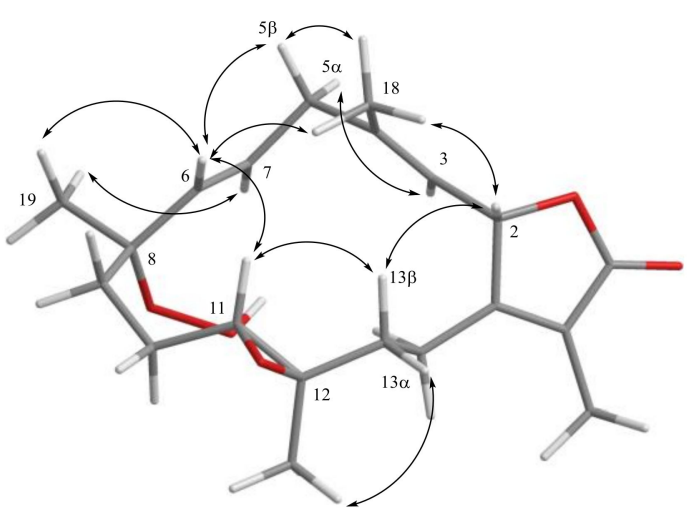

2

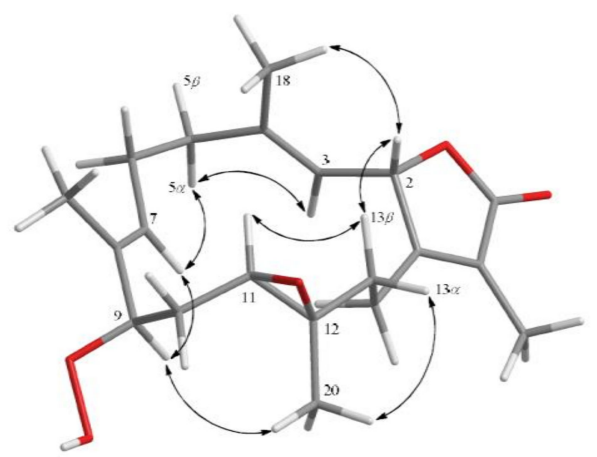

4

Figure 3. Key NOE correlations for 1-4. 
The molecular formula of cherbonolide $\mathrm{G}(2)$ was found to be $\mathrm{C}_{20} \mathrm{H}_{28} \mathrm{O}_{5}$ by analysis of HR-ESI-MS $\left(\mathrm{m} / \mathrm{z}\right.$ calculated 371.1829; found 371.1830, $\left.[\mathrm{M}+\mathrm{Na}]^{+}\right)$, revealing that 2 possesses an additional oxygen atom to that of $\mathbf{1}$. Moreover, both $\mathbf{1}$ and $\mathbf{2}$ showed the very similar ${ }^{1} \mathrm{H}$ - and ${ }^{13} \mathrm{C}-\mathrm{NMR}$ data (Table 1 ), except that the chemical shift of C-8 was shifted from $\delta_{C} 71.7$ of $\mathbf{1}$ to $\delta_{\mathrm{C}} 83.7$ of $\mathbf{2}$. The very similar COSY, HMBC (Figure 2), and NOE (Figure 3) correlations of $\mathbf{1}$ and $\mathbf{2}$ also revealed the very close structures for both compounds. However, the hydroxy group of $\mathbf{1}$ at C-8 was replaced by a hydroperoxy group in $\mathbf{2}$, with a broad singlet appearing at $\delta_{\mathrm{H}} 6.72$ and the downfield shift of C-8. Accordingly, the molecular skeleton and the $(2 S, 8 S, 11 R, 12 R)$-configuration of 2 were determined.

Cherbonolide $\mathrm{H}$ (3) has the same molecular formula as that of $\mathbf{1}$, as determined by HR-ESI-MS experiment. Moreover, most of the ${ }^{1} \mathrm{H}-{ }^{1} \mathrm{H}$ COSY and HMBC correlations (Figure 2) of $\mathbf{3}$ were similar to those of isosarcophine except for the presence of a hydroxyl at $\mathrm{C}-9$ leading to the shift of $\mathrm{CH}-9$ to lower field $\left(\delta_{\mathrm{C}} 76.2 ; \delta_{\mathrm{H}} 3.68\right)$, and the shift of C-6/C-7 double bond of $\mathbf{1}$ to C-7/C-8 double bond of 3 . Analysis of NOE correlations (Figure 3) showed that the $\beta$-oriented H-2 exhibited NOE interactions with both $\mathrm{H}_{3}-18$ and $\mathrm{H}-13 \beta$, but not with $\mathrm{H}-3$, assigning the E-geometry of the trisubstituted C-3/C-4 double bond. These results, along with the found NOE correlations (Figure 3) of $\mathrm{H}-13 \alpha / \mathrm{H}_{3}-20, \mathrm{H}_{3}-20 / \mathrm{H}-9$, led to the assignment of the $\alpha$-orientation of $\mathrm{H}-9$.

Cherbonolide I (4) was found to contain one additional oxygen atom than 3, according to HR-ESI-MS experiment. These two compounds also showed very similar ${ }^{1} \mathrm{H}-{ }^{1} \mathrm{H}$ COSY and HMBC correlations, revealing the identical molecular framework of both compounds. NMR data of 3 and 4 were similar (Table 1), except for those of $\mathrm{CH}-9$, suggesting that 4 is possibly the $\mathrm{C}-9$ hydroperoxy derivative of 3. By analysis of NOE correlations (Figure 3), the $E$ geometries of both C-3/C-4 and C-7/C-8 double bonds of 4 and the $(2 S, 9 R, 11 R, 12 R)$-configuration were also established. Reduction of 4 by triphenylphosphine yielded 3, further confirming the structure of 4 .

Cherbonolide J (5) was given as a colorless oil with a molecular formula $\mathrm{C}_{20} \mathrm{H}_{30} \mathrm{O}_{5}$ on the basis of HR-ESI-MS data $\left(\mathrm{m} / z\right.$ calculated for $\mathrm{C}_{20} \mathrm{H}_{30} \mathrm{O}_{5} \mathrm{Na} 373.1986$; found 373.1984), revealing six degrees of unsaturation. The IR absorptions at 3443 and $1748 \mathrm{~cm}^{-1}$ were due to hydroxy and ester carbonyl groups, respectively. The ${ }^{13} \mathrm{C}$ - and ${ }^{1} \mathrm{H}-\mathrm{NMR}$ spectroscopic data (Tables 1 and 3 ) of 5 measured at $\mathrm{C}_{6} \mathrm{D}_{6}$ were very close to a known compound sarcophyolide E [29], and the 2D NMR (COSY, HSQC, and HMBC) correlation analysis revealed that both compounds had the same molecular framework (Figure 4). Detailed analysis of the NOE correlations (Figure 5) showed that both compounds possessed the same relative configuration. However, the $[\alpha]_{25}^{\mathrm{D}}$ values in $\mathrm{CHCl}_{3}$ (-6 for 5 and +4.4 for sarcophyolide E) were close but with different signs, suggesting that $\mathbf{5}$ is the enantiomer of this known compound. The absolute configurations of $\mathbf{5}$ and sarcophyolide $\mathrm{E}$ were deduced by comparison of the circular dichroism (CD) spectroscopic data. As shown in Figure 6, the negative Cotton effect at $247 \mathrm{~nm}$ and positive effect at $228 \mathrm{~nm}$ for 5 in comparison with the positive and negative Cotton effects at 252 and $226 \mathrm{~nm}$ for sarcophyolide E [29], respectively, confirmed that $\mathbf{5}$ is the newly found enantiomer of sarcophyolide E.
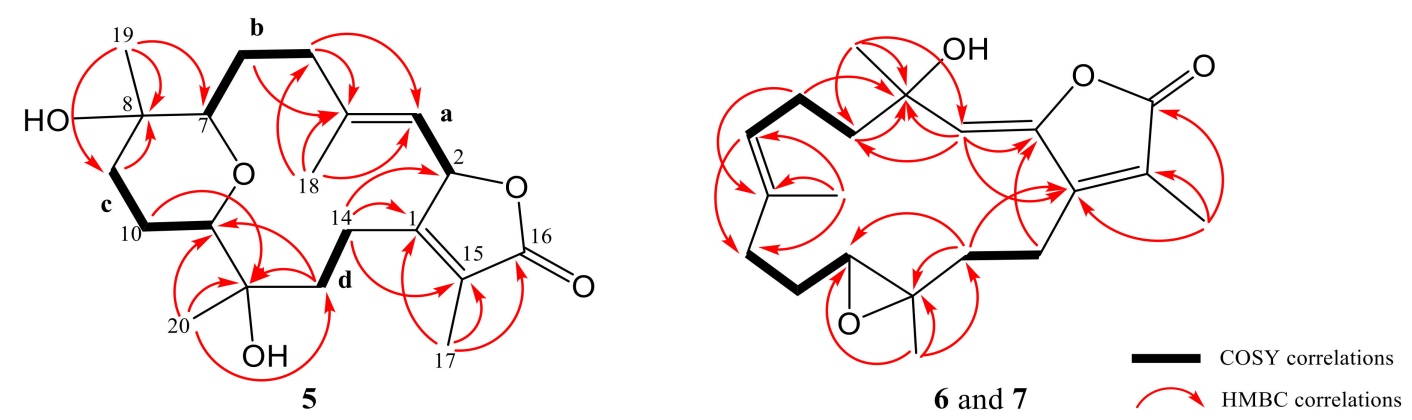

Figure 4. Selected COSY and HMBC correlations of 5-7. 


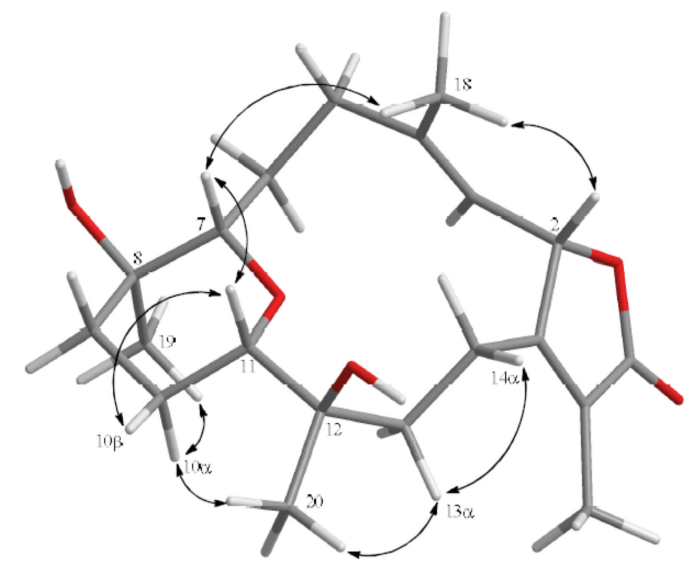

5

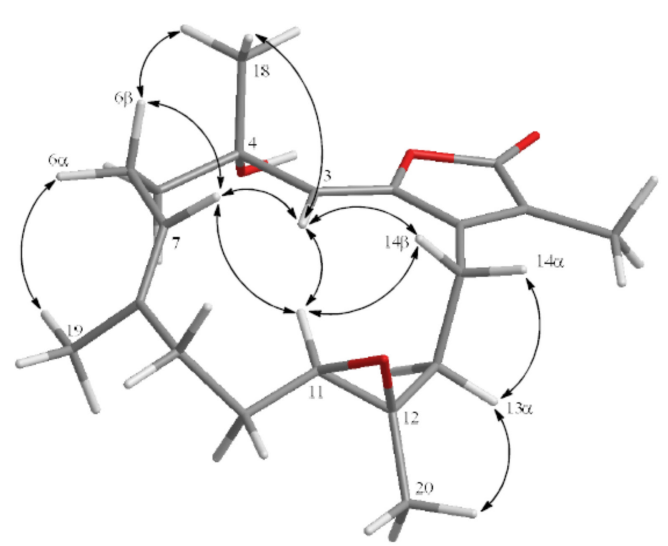

6

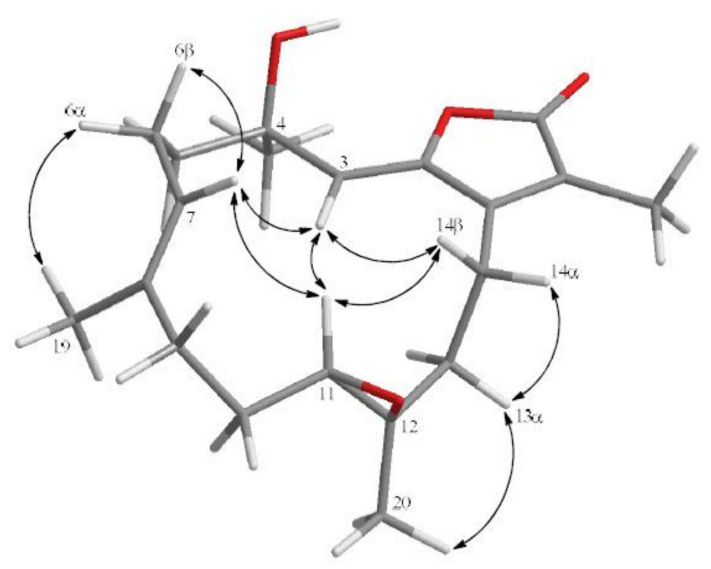

7

Figure 5. Selected NOE correlations for 5-7.

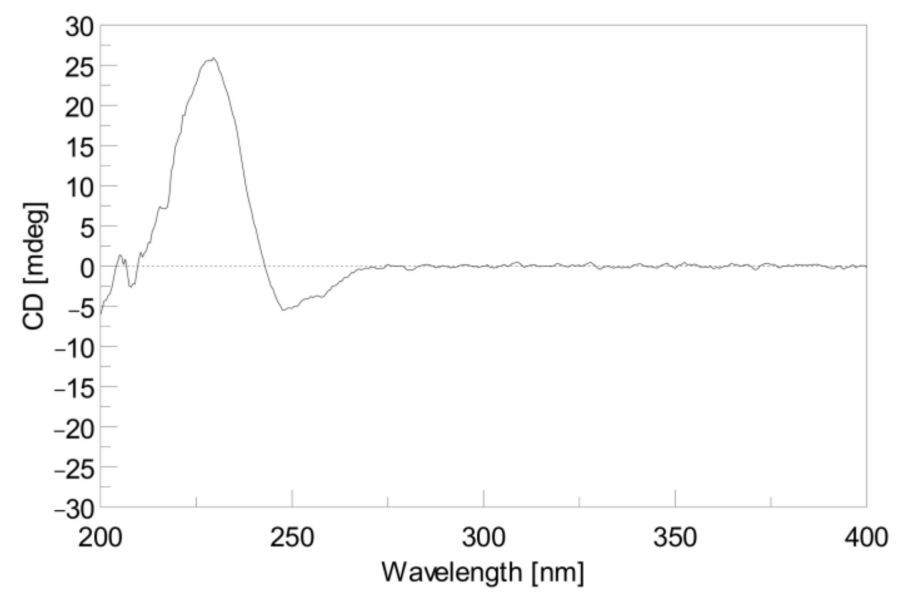

Figure 6. the CD spectrum of $5\left(1.2 \times 10^{-4} \mathrm{M}, \mathrm{MeOH}\right)$.

Cherbonolide $\mathrm{K}(6)$ is a colorless oil which was shown to have the molecular formula $\mathrm{C}_{20} \mathrm{H}_{28} \mathrm{O}_{4}$ by HR-ESI-MS experiment, appropriate for seven degrees of unsaturation. The infrared (IR) spectrum 
of 6 showed peaks of hydroxy and estercarbonyl groups at 3444 and $1763 \mathrm{~cm}^{-1}$, respectively. ${ }^{13} \mathrm{C}-\mathrm{NMR}$ data (Table 1) with signals at $\delta_{\mathrm{C}} 151.2(\mathrm{C}), 147.2(\mathrm{C}), 116.2(\mathrm{CH}), 72.7(\mathrm{C}), 123.6(\mathrm{C}), 169.5(\mathrm{C}), 9.1\left(\mathrm{CH}_{3}\right)$, and $29.9\left(\mathrm{CH}_{3}\right)$ and ${ }^{1} \mathrm{H}$ NMR data (Table 3$)$ with signals at $\delta_{\mathrm{H}} 5.50(\mathrm{~s}, 1 \mathrm{H}), 1.95(\mathrm{~s}, 3 \mathrm{H})$, and $1.41(\mathrm{~s}$, $3 \mathrm{H})$ were attributed to the cembranoidal $\alpha$-methyl- $\alpha, \beta$-unsaturated- $\gamma$ lactone ring with a conjugated 2,3-double bond that further connected with the methyl and hydroxyl substituted C-4. The above results were supported by HMBC correlations of 6 (Figure 4$)$ from H-3 $\left(\delta_{\mathrm{H}} 5.50\right)$ to C-1 $\left(\delta_{\mathrm{C}} 151.2\right)$, C-2 $\left(\delta_{\mathrm{C}} 147.2\right)$, and C-4 $\left(\delta_{\mathrm{C}} 72.7\right), \mathrm{H}_{3}-17\left(\delta_{\mathrm{H}} 1.95\right)$ to $\mathrm{C}-1, \mathrm{C}-15\left(\delta_{\mathrm{C}} 123.6\right)$, and C-16 $\left(\delta_{\mathrm{C}} 169.5\right)$, and $\mathrm{H}_{3}-18$ $\left(\delta_{\mathrm{H}} 1.41\right)$ to $\mathrm{C}-3\left(\delta_{\mathrm{C}} 116.2\right)$ and $\mathrm{C}-4\left(\delta_{\mathrm{C}} 72.6\right)$. The remainder of the structure from $\mathrm{C}-5$ to $\mathrm{C}-14$ was found to be identical to isosarcophine [24]. Thus, the planar structure of 6 was established. Furthermore, the NOE correlation analysis shown in Figure 5 revealed the $\alpha$-orientations of $4-\mathrm{OH}$ and $12-\mathrm{CH}_{3}$, $\beta$-orientation of H-11, (Z)-2,3-double bond, and (E)-7,8-double bond. An isomer of 6, cherbonolide L (7), was also subsequently isolated. The metabolite 7 had nearly the same NMR data as 6 except for $\mathrm{CH}_{2}-5$ and $\mathrm{CH}_{2}-6$. Thus, it can be assumed that 7 is the $\mathrm{C}-4$ epimer of 6 . Analysis of the 2D NMR correlations of 7 (Figures 4 and 6) further supported this assumption.

For the screening of bioactivities, the anti-inflammation activities of 1-7 toward inhibition of $N$-formyl-methionyl-leucyl-phenylalanine/cytochalasin B (fMLF/CB)-induced generation of superoxide anion $\left(\mathrm{O}_{2}{ }^{--}\right)$and release of elastase in primary human neutrophils were measured. The results (Table 4) showed that, although none of the isolates exhibited strong inhibitory activities in the assay, 2 and 3 were found to display notable ability to inhibit the elastase release $(48.2 \% \pm 6.2 \%)$ and superoxide anion generation $(44.5 \% \pm 4.6 \%)$ at $30 \mu \mathrm{M}$, respectively. In comparison with $(+)$-isosarcophine, cherbonolides A-E, and bischerbonolide peroide discovered previously from S. cherbonnieri [24], it was found that, although 2 and 3 exhibited weaker activities than bischerbonolide peroxide, they displayed comparable activities to those of cherbonolides $\mathrm{A}$ and $\mathrm{C}$. In general, allylic oxidation at the 7,8-double bond of (+)-isosarcophine might be able to produce derivatives with stronger bioactivities.

Table 4. Inhibitory effects of metabolites 1-7 against elastase release and superoxide anion generation in N-formyl-methionyl-leucyl-phenylalanine/cytochalasin B (fMLF/CB)-induced primary human neutrophils. $\mathrm{IC}_{50}$, half maximal inhibitory concentration.

\begin{tabular}{|c|c|c|c|c|}
\hline \multirow{2}{*}{ Compound } & \multicolumn{2}{|c|}{ Superoxide Anion } & \multicolumn{2}{|c|}{ Elastase Release } \\
\hline & $\mathrm{IC}_{50}(\mu \mathrm{M})^{\mathrm{a}}$ & $\operatorname{Inh} \mathbf{b} \%$ & $\mathrm{IC}_{50}(\mu \mathrm{M})^{\mathrm{a}}$ & $\operatorname{Inh}^{\mathrm{b}} \%$ \\
\hline 1 & $>30$ & $11.0 \pm 8.7$ & $>30$ & $35.1 \pm 10.6^{* * *}$ \\
\hline 2 & $>30$ & $29.8 \pm 9.8^{* *}$ & $>30$ & $48.2 \pm 12.5^{* * *}$ \\
\hline 3 & $>30$ & $44.5 \pm 7.9^{* * *}$ & $>30$ & $35.6 \pm 10.7^{* * *}$ \\
\hline 4 & $>30$ & $6.4 \pm 7.3$ & $>30$ & $27.6 \pm 12.8^{* *}$ \\
\hline 5 & $>30$ & $6.2 \pm 5.5$ & $>30$ & $29.7 \pm 11.1^{* *}$ \\
\hline 6 & $>30$ & $12.9 \pm 11.4$ & $>30$ & $16.7 \pm 10.2 *$ \\
\hline 7 & $>30$ & $17.1 \pm 11.6^{*}$ & $>30$ & $27.6 \pm 12.0 * *$ \\
\hline Idelalisib & $0.07 \pm 0.03$ & $102.8 \pm 5.4^{* * *}$ & $0.07 \pm 0.02$ & $99.6 \pm 10.3^{* * *}$ \\
\hline
\end{tabular}

${ }^{a}$ Concentration necessary for $50 \%$ inhibition $\left(\mathrm{IC}_{50}\right) .{ }^{\mathrm{b}}$ Percentage of inhibition (Inh \%) at $30 \mu \mathrm{M}$. Results presented as mean \pm S.D. The anti-inflammatory assays were performed with eight biological replicates. ${ }^{*} p<0.05,{ }^{* *} p<0.01$, and ${ }^{* * *} p<0.001$ compared with the control.

\section{Materials and Methods}

\subsection{General Experimental Procedures}

Values of the specific optical rotation of the isolates were measured with a JASCO P-1020 polarimeter (JASCO Corporation, Tokyo, Japan). Infrared spectra were recorded using a JASCO FT/IR-4100 infrared spectrophotometer (JASCO Corporation, Tokyo, Japan). The CD spectrum was recorded on a Jasco J-815 circular dichroism (CD) spectropolarimeter (JASCO, Tokyo, Japan) in MeOH. ${ }^{1} \mathrm{H}$ - and ${ }^{13} \mathrm{C}-\mathrm{NMR}$ spectra were acquired on a Varian 400MR FT-NMR (or Varian Unity INOVA500 FT-NMR) instrument (Varian Inc., Palo Alto, CA, USA) at $400 \mathrm{MHz}$ (or $500 \mathrm{MHz}$ ) and $100 \mathrm{MHz}$ (or 
$125 \mathrm{MHz})$, respectively, in $\mathrm{CDCl}_{3}$ or $\mathrm{C}_{6} \mathrm{D}_{6}$. LR-ESI-MS and HR-ESI-MS experiments were carried out using a Bruker APEX II (Bruker, Bremen, Germany) mass spectrometer. Silica gel (230-400 mesh) was used as the adsorbent for normal-phase column chromatography. Thin-layer chromatography (TLC) analyses were performed with precoated silica gel plates (Kieselgel 60 F-254, $0.2 \mathrm{~mm}$, Merck, Darmstadt, Germany). Further purification of impure fractions or compounds was further achieved by high-performance liquid chromatography on a Hitachi L-7100 HPLC instrument (Hitachi Ltd., Tokyo, Japan) with a Merck Hibar Si-60 column (250 mm × 21 mm, $7 \mu \mathrm{m}$; Merck, Darmstadt, Germany) and on a Hitachi L-2455 HPLC apparatus (Hitachi, Tokyo, Japan) with a Supelco C18 column (250 mm $\times$

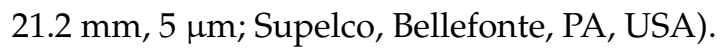

\subsection{Animal Materials}

The marine organism S. cherbonnieri was collected and preserved as described previously [24].

\subsection{Extraction and Isolation}

By using the procedure reported previously, $1.2 \mathrm{~kg}$ (wet weight) of organism S. cherbonnieri was dehydrated, minced, extracted, and concentrated to afford $10.2 \mathrm{~g}$ of residue. The residue was fractionated by chromatography to yield 19 fractions [24]. Fraction 10, eluting with $n$-hexane-acetone (4:1), was further purified over silica gel using $n$-hexane-acetone (6:1) to afford seven subfractions (A1-A7). Subfraction A3 was further separated by reverse-phase HPLC using acetonitrile- $\mathrm{H}_{2} \mathrm{O}$ (1:1.1) to afford $2(1.4 \mathrm{mg})$. Subfraction A4 was purified by reverse-phase HPLC using acetonitrile- $\mathrm{H}_{2} \mathrm{O}$ $(1: 1.2)$ to afford $4(8.8 \mathrm{mg})$, and subfraction A6 was purified by reverse-phase HPLC acetonitrile- $\mathrm{H}_{2} \mathrm{O}$ (2:1) to afford 5 ( $3.1 \mathrm{mg})$. Fractions 11 and 12, obtained by eluting with $n$-hexane-acetone 3:1 and 2:1, respectively, were combined and further eluted with acetone by a Sephadex LH-20 column to afford six subfractions (B1-B6). The purification of subfractions $\mathrm{B} 4$ and $\mathrm{B} 5$ using reverse-phase HPLC by elution of acetonitrile- $\mathrm{H}_{2} \mathrm{O}(1: 1.3)$ and $\mathrm{MeOH}-\mathrm{H}_{2} \mathrm{O}(3: 2)$ afforded 6 (12.4 mg) and 7 (33.1 mg), respectively. Fraction 13, eluting with $n$-hexane-acetone (1:1), was purified by eluting with acetone on Sephadex LH-20 to yield five subfractions (C1-C5). Subfraction C2 was further separated by reverse-phase HPLC using acetonitrile- $\mathrm{H}_{2} \mathrm{O}(1: 1.4)$ to afford $\mathbf{1}(3.3 \mathrm{mg})$ and $\mathbf{3}(10.8 \mathrm{mg})$.

Cherbonolide F (1): colorless oil; $[\alpha]_{25}^{\mathrm{D}}+177$ ( $\left.c 0.50, \mathrm{CHCl}_{3}\right)$; IR (neat) $\nu_{\max } 3460,2967,2928,2864,1748$, $1677,1452,1385,1096,984$, and $755 \mathrm{~cm}^{-1}$; for ${ }^{13} \mathrm{C}$ - and ${ }^{1} \mathrm{H}-\mathrm{NMR}$ data $\left(400 \mathrm{MHz} ; \mathrm{C}_{6} \mathrm{D}_{6}\right)$, see Tables 1 and 2; ESI-MS $m / z 355[\mathrm{M}+\mathrm{Na}]^{+}$; HR-ESI-MS $m / z 355.1879[\mathrm{M}+\mathrm{Na}]^{+}$(calculated for $\mathrm{C}_{20} \mathrm{H}_{28} \mathrm{O}_{4} \mathrm{Na}$, 355.1880).

Cherbonolide G (2): colorless oil; $[\alpha]_{25}^{\mathrm{D}}+25$ (c 0.33, $\left.\mathrm{CHCl}_{3}\right)$; IR (neat) $v_{\max } 3419,2925,2855,1748,1678$, 1454, 1387, 1096, 987, and $755 \mathrm{~cm}^{-1}$; for ${ }^{13} \mathrm{C}$ - and ${ }^{1} \mathrm{H}-\mathrm{NMR}$ data $\left(400 \mathrm{MHz} ; \mathrm{C}_{6} \mathrm{D}_{6}\right)$, see Tables 1 and 2;

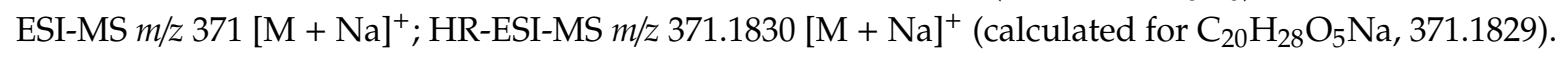

Cherbonolide H (3): colorless oil; $[\alpha]_{25}^{\mathrm{D}}+41$ (c 1.00, $\left.\mathrm{CHCl}_{3}\right)$; IR (neat) $v_{\max } 3445,2928,2864,1747,1679$, $1455,1387,1094,996$, and $755 \mathrm{~cm}^{-1}$; for ${ }^{13} \mathrm{C}$ - and ${ }^{1} \mathrm{H}-\mathrm{NMR}$ data $\left(400 \mathrm{MHz} ; \mathrm{C}_{6} \mathrm{D}_{6}\right.$ ), see Tables 1 and 2; ESI-MS $m / z 355[\mathrm{M}+\mathrm{Na}]^{+}$; HR-ESI-MS $m / z 355.1878[\mathrm{M}+\mathrm{Na}]^{+}$(calculated for $\mathrm{C}_{20} \mathrm{H}_{28} \mathrm{O}_{4} \mathrm{Na}$, 355.1880).

Cherbonolide I (4): colorless oil; $[\alpha]_{25}^{\mathrm{D}}+13$ (c 1.00, $\mathrm{CHCl}_{3}$ ); IR (neat) $v_{\max } 3420,2925,2855,1747,1541$, 1390, 992, and $756 \mathrm{~cm}^{-1}$; for ${ }^{13} \mathrm{C}$ - and ${ }^{1} \mathrm{H}-\mathrm{NMR}$ data $\left(500 \mathrm{MHz} ; \mathrm{C}_{6} \mathrm{D}_{6}\right)$, see Tables 1 and 2; ESI-MS $\mathrm{m} / \mathrm{z}$ $371[\mathrm{M}+\mathrm{Na}]^{+}$; HR-ESI-MS m/z $371.1828[\mathrm{M}+\mathrm{Na}]^{+}$(calculated for $\mathrm{C}_{20} \mathrm{H}_{28} \mathrm{O}_{5} \mathrm{Na}$, 371.1829).

Cherbonolide J (5): white powder; $[\alpha]_{25}^{\mathrm{D}}-6\left(c 0.50, \mathrm{CHCl}_{3}\right)$; IR (neat) $v_{\max } 3443,2937,2860,1755,1675$, 1381, 1076, 990, and $755 \mathrm{~cm}^{-1} ; \mathrm{CD}\left(1.2 \times 10^{-4} \mathrm{M}, \mathrm{MeOH}\right) \lambda_{\max }(\Delta \varepsilon) 247(-5.2)$, and $228(+26.5) \mathrm{nm}$; for ${ }^{13} \mathrm{C}$ - and ${ }^{1} \mathrm{H}-\mathrm{NMR}$ data $\left(400 \mathrm{MHz} ; \mathrm{C}_{6} \mathrm{D}_{6}\right)$, see Tables 1 and 3 ; ESI-MS $m / z 373[\mathrm{M}+\mathrm{Na}]^{+}$; HR-ESI-MS $\mathrm{m} / \mathrm{z} 373.1984[\mathrm{M}+\mathrm{Na}]^{+}$(calculated for $\mathrm{C}_{20} \mathrm{H}_{30} \mathrm{O}_{5} \mathrm{Na}, 373.1986$ ). 
Cherbonolide K (6): yellow oil; $[\alpha]_{25}^{\mathrm{D}}+12\left(c 1.00, \mathrm{CHCl}_{3}\right)$; IR (neat) $v_{\max } 3444,2927,1763,1435,1386$, $1241,1083,931$, and $756 \mathrm{~cm}^{-1}$; for ${ }^{13} \mathrm{C}$ - and ${ }^{1} \mathrm{H}-\mathrm{NMR}$ data $\left(400 \mathrm{MHz} ; \mathrm{CDCl}_{3}\right)$, see Tables 1 and 3; ESI-MS $\mathrm{m} / \mathrm{z} 355[\mathrm{M}+\mathrm{Na}]^{+} ;$HR-ESI-MS $\mathrm{m} / \mathrm{z} 355.1880[\mathrm{M}+\mathrm{Na}]^{+}$(calculated for $\mathrm{C}_{20} \mathrm{H}_{28} \mathrm{O}_{4} \mathrm{Na}$, 355.1880).

Cherbonolide L (7): yellow oil; $[\alpha]_{25}^{\mathrm{D}}+33\left(c\right.$ 1.00, $\left.\mathrm{CHCl}_{3}\right)$; IR (neat) $v_{\max } 3445,2929,2872,1752,1665$, 1455, 1384, 1050, 927, and $756 \mathrm{~cm}^{-1}$; for ${ }^{13} \mathrm{C}$ - and ${ }^{1} \mathrm{H}-\mathrm{NMR}$ data $\left(400 \mathrm{MHz} ; \mathrm{CDCl}_{3}\right.$ ), see Tables 1 and 3;

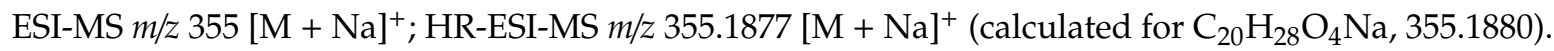

\subsection{Reduction of Cherbonolide I (4)}

The solution of compound $4(1.4 \mathrm{mg})$ in diethyl ether $(5.0 \mathrm{~mL})$ was added to an excess amount of triphenylphosphine $(1.3 \mathrm{mg})$, and the mixture was stirred at room temperature for $4 \mathrm{~h}$. The solvent of the solution was evaporated under reduced pressure to afford a residue, which was purified by silica gel column chromatography using $n$-hexane-acetone (3:1) as an eluent to yield 3 (1.0 mg, $75 \%$ ).

\subsection{In Vitro Anti-Inflammatory Assay}

\subsubsection{Primary Human Neutrophils}

Blood was obtained from the elbow vein of healthy adult volunteers (with ages 20-30). Neutrophils were enriched by means of dextran sedimentation, Ficoll-Hypaque centrifugation, and hypotonic lysis. Neutrophils were incubated in an ice-cold $\mathrm{Ca}^{2+}$-free Hank's Balanced Salt Solution (HBSS buffer, $\mathrm{pH}$ 7.4) [31]. The research protocol was granted approval by the institutional review board of Chang Gung Memorial Hospital (IRB No: 201601307A3, 20161124-20191123; 201902217A3, 20200501-20240630). All subjects gave their informed consent for inclusion before they participated in the study. The study was conducted in accordance with the Declaration of Helsinki.

\subsubsection{Superoxide Anion Generation}

Neutrophils $\left(6 \times 10^{5}\right.$ cells $\left.\cdot \mathrm{mL}^{-1}\right)$ incubated in HBSS with ferricytochrome $c\left(0.5 \mathrm{mg} \cdot \mathrm{mL}^{-1}\right)$ and $\mathrm{Ca}^{2+}(1 \mathrm{mM})$ at $37^{\circ} \mathrm{C}$ were treated with dimethyl sulfoxide (DMSO), as control, or with the tested compound for $5 \mathrm{~min}$. Neutrophils were primed by cytochalasin $B\left(C B, 1 \mu \mathrm{g} \cdot \mathrm{mL}^{-1}\right)$ for $3 \mathrm{~min}$ before activating fMLF (100 nM) for $10 \mathrm{~min}(\mathrm{fMLF} / \mathrm{CB})$. The change in superoxide anion generation was spectrophotometrically measured at $550 \mathrm{~nm}$ (U-3010, Hitachi, Tokyo, Japan) [32,33].

\subsubsection{Elastase Release}

Neutrophils $\left(6 \times 10^{5}\right.$ cells $\left.\cdot \mathrm{mL}^{-1}\right)$ incubated in HBSS with MeO-Suc-Ala-Ala-Pro-Val- $p$ - nitroanilide $(100 \mu \mathrm{M})$ and $\mathrm{Ca}^{2+}(1 \mathrm{mM})$ at $37^{\circ} \mathrm{C}$ were treated with DMSO or the tested compound for $5 \mathrm{~min}$. Neutrophils were challenged by fMLF $(100 \mathrm{nM}) / \mathrm{CB}\left(0.5 \mu \mathrm{g} \cdot \mathrm{mL}^{-1}\right)$ for $10 \mathrm{~min}$. The change in elastase release was spectrophotometrically measured at $405 \mathrm{~nm}$ (U-3010, Hitachi, Tokyo, Japan) [32].

\subsubsection{Statistical Analysis}

Data were displayed as the mean $\pm \mathrm{SD}$, and comparisons were performed by one-way ANOVA with Dunnett analysis. All results were obtained from eight biological replicates. A probability value of 0.05 or less was considered to be significant. The Prism software (Version 5.0, GraphPad Software, San Diego, CA, USA) was used for the statistical analysis.

\section{Conclusions}

Our present examination of the chemical constituents of the soft coral S. cherbonnieri led to the discovery of new cembranoid compounds 1-7. All compounds were found to possess anti-inflammatory activity by exhibiting inhibitory effects on the generation of superoxide anion and elastase release in fMLF/CB-induced primary human neutrophils, and cherbonolides $\mathrm{G}$ and $\mathrm{H}$ ( 2 and 3 ) were found to be the most active in the inhibition of elastase release and superoxide anion generation, respectively. 
As the marine environment is an important source of bioactive substances, and due to the high chemical diversity and specimen diversity of the Sarcophyton genus $[27,28,34,35]$, it can be expected that new natural products and activities from soft corals of this genus can be continuously discovered in the future.

Supplementary Materials: The following are available online at http://www.mdpi.com/1660-3397/18/11/573/s1. HR-ESI-MS, ${ }^{1} \mathrm{H}-\mathrm{NMR},{ }^{13} \mathrm{C}-\mathrm{NMR}$, DEPT, HMQC, COSY, HMBC, and NOESY spectra of new compounds 1-7 are available online at http://www.mdpi.com/1660-3397/16/8/276/s1. Figure S1: HR-ESI-MS spectrum of 1; Figure S2. ${ }^{1} \mathrm{H}-\mathrm{NMR}$ spectrum of $\mathbf{1}$ in $\mathrm{C}_{6} \mathrm{D}_{6}$; Figure S3. ${ }^{13} \mathrm{C}-\mathrm{NMR}$ spectrum of $\mathbf{1}$ in $\mathrm{C}_{6} \mathrm{D}_{6}$; Figure S4. HSQC spectrum of $\mathbf{1}$ in $\mathrm{C}_{6} \mathrm{D}_{6}$; Figure $\mathrm{S} 5 .{ }^{1} \mathrm{H}-{ }^{1} \mathrm{H}$ COSY spectrum of $\mathbf{1}$ in $\mathrm{C}_{6} \mathrm{D}_{6}$; Figure $\mathrm{S} 6$. HMBC spectrum of $\mathbf{1}$ in $\mathrm{C}_{6} \mathrm{D}_{6}$; Figure S7. NOESY spectrum of $\mathbf{1}$ in $\mathrm{C}_{6} \mathrm{D}_{6}$; Figure S8. HR-ESI-MS spectrum of 2; Figure S9. ${ }^{1} \mathrm{H}-\mathrm{NMR}$ spectrum of $\mathbf{2}$ in $\mathrm{C}_{6} \mathrm{D}_{6}$; Figure S10. ${ }^{13} \mathrm{C}-\mathrm{NMR}$ spectrum of 2 in $\mathrm{C}_{6} \mathrm{D}_{6}$; Figure S11. HSQC spectrum of 2 in $\mathrm{C}_{6} \mathrm{D}_{6}$; Figure $\mathrm{S} 12 .{ }^{1} \mathrm{H}-{ }^{1} \mathrm{H}$ COSY spectrum of 2 in $\mathrm{C}_{6} \mathrm{D}_{6}$; Figure S13. HMBC spectrum of $\mathbf{2}$ in $\mathrm{C}_{6} \mathrm{D}_{6}$; Figure S14. NOESY spectrum of $\mathbf{2}$ in $\mathrm{C}_{6} \mathrm{D}_{6}$; Figure S15. HR-ESI-MS spectrum of 3; Figure S16. ${ }^{1} \mathrm{H}-\mathrm{NMR}$ spectrum of 3 in $\mathrm{C}_{6} \mathrm{D}_{6}$; Figure S17. ${ }^{13} \mathrm{C}-\mathrm{NMR}$ spectrum of 3 in $\mathrm{C}_{6} \mathrm{D}_{6}$; Figure S18. HSQC spectrum of 3 in $\mathrm{C}_{6} \mathrm{D}_{6}$; Figure S19. ${ }^{1} \mathrm{H}-{ }^{1} \mathrm{H}$ COSY spectrum of 3 in $\mathrm{C}_{6} \mathrm{D}_{6}$; Figure S20. HMBC spectrum of 3 in $\mathrm{C}_{6} \mathrm{D}_{6}$; Figure S21. NOESY spectrum of 3 in $\mathrm{C}_{6} \mathrm{D}_{6}$; Figure S22. HR-ESI-MS spectrum of 4; Figure S23. ${ }^{1} \mathrm{H}-\mathrm{NMR}$ spectrum of 4 in $\mathrm{C}_{6} \mathrm{D}_{6}$; Figure S24. ${ }^{13} \mathrm{C}-\mathrm{NMR}$ spectrum of 4 in $\mathrm{C}_{6} \mathrm{D}_{6}$; Figure S25. HSQC spectrum of 4 in $\mathrm{C}_{6} \mathrm{D}_{6}$; Figure S26. ${ }^{1} \mathrm{H}-{ }^{1} \mathrm{HCOSY}$ spectrum of 4 in $\mathrm{C}_{6} \mathrm{D}_{6}$; Figure S27. HMBC spectrum of 4 in $\mathrm{C}_{6} \mathrm{D}_{6}$; Figure S28. NOESY spectrum of 4 in $\mathrm{C}_{6} \mathrm{D}_{6}$; Figure S29. HR-ESI-MS spectrum of 5; Figure S30. ${ }^{1} \mathrm{H}-\mathrm{NMR}$ spectrum of 5 in $\mathrm{C}_{6} \mathrm{D}_{6}$; Figure S31. ${ }^{13} \mathrm{C}$-NMR spectrum of 5 in $\mathrm{C}_{6} \mathrm{D}_{6}$; Figure S32. HSQC spectrum of 5 in $\mathrm{C}_{6} \mathrm{D}_{6}$; Figure S33. ${ }^{1} \mathrm{H}-{ }^{1} \mathrm{H}$ COSY spectrum of 5 in $\mathrm{C}_{6} \mathrm{D}_{6}$; Figure S34. HMBC spectrum of 5 in $\mathrm{C}_{6} \mathrm{D}_{6}$; Figure S35. NOESY spectrum of 5 in $\mathrm{C}_{6} \mathrm{D}_{6}$; Figure S36. HR-ESI-MS spectrum of 6 ; Figure S37. ${ }^{1} \mathrm{H}$-NMR spectrum of $\mathbf{6}$ in $\mathrm{CDCl}_{3}$; Figure S38. ${ }^{13} \mathrm{C}-\mathrm{NMR}$ spectrum of 6 in $\mathrm{CDCl}_{3}$; Figure S39. HSQC spectrum of 6 in $\mathrm{CDCl}_{3}$; Figure S40. ${ }^{1} \mathrm{H}-{ }^{1} \mathrm{H}$ COSY spectrum of 6 in $\mathrm{CDCl}_{3}$; Figure S41. HMBC spectrum of 6 in $\mathrm{CDCl}_{3}$; Figure S42. NOESY spectrum of 6 in $\mathrm{CDCl}_{3}$; Figure S43. HR-ESI-MS spectrum of 7; Figure S44. ${ }^{1} \mathrm{H}$-NMR spectrum of 7 in $\mathrm{CDCl}_{3}$; Figure S45. ${ }^{13} \mathrm{C}$-NMR spectrum of 7 in $\mathrm{CDCl}_{3}$; Figure S46. HSQC spectrum of 7 in $\mathrm{CDCl}_{3}$; Figure S47. ${ }^{1} \mathrm{H}-{ }^{1} \mathrm{H}$ COSY spectrum of $\mathbf{7}$ in $\mathrm{CDCl}_{3}$; Figure $\mathrm{S} 48$. HMBC spectrum of $\mathbf{7}$ in $\mathrm{CDCl}_{3}$; Figure $\mathrm{S49}$. NOESY spectrum of $\mathbf{7}$ in $\mathrm{CDCl}_{3}$.

Author Contributions: Conceptualization, J.-H.S.; investigation, C.-C.P.; analysis, C.-C.P. and C.-Y.H.; writing-original draft, C.-Y.H., J.-H.S., and A.F.A.; writing—review and editing, J.-H.S.; anti-inflammatory assay, T.-L.H. All authors read and agreed to the published version of the manuscript.

Funding: Financial support of this work from the Ministry of Science and Technology of Taiwan (MOST 104-2113-M-110-006, 104-2320-B-110-001-MY2, and 107-2320-B-110-001-MY3) to J.-H.S. and further funding from the Deanship of Scientific Research at King Saud University through research group RG-1440-127.

Conflicts of Interest: The authors declare no conflict of interest.

\section{References}

1. Farag, M.A.; Fekry, M.I.; Al-Hammady, M.A.; Khalil, M.N.; El-Seedi, H.R.; Meyer, A.; Porzel, A.; Westphal, H.; Wessjohann, L.A. Cytotoxic effects of Sarcophyton sp. soft corals-is there a correlation to their NMR fingerprints? Mar. Drugs 2017, 15, 211. [CrossRef]

2. Chao, C.H.; Li, W.L.; Huang, C.Y.; Ahmed, A.F.; Dai, C.F.; Wu, Y.C.; Lu, M.C.; Liaw, C.C.; Sheu, J.H. Isoprenoids from the soft coral Sarcophyton glaucum. Mar. Drugs 2017, 15, 202. [CrossRef]

3. Hegazy, M.E.F.; Elshamy, A.I.; Mohamed, T.A.; Hamed, A.R.; Ibrahim, M.A.A.; Ohta, S.; Paré, P.W. Cembrene diterpenoids with ether linkages from Sarcophyton ehrenbergi: An anti-proliferation and molecular-docking assessment. Mar. Drugs 2017, 15, 192. [CrossRef]

4. Elkhateeb, A.; El-Beih, A.A.; Gamal-Eldeen, A.M.; Alhammady, M.A.; Ohta, S.; Paré, P.W.; Hegazy, M.E.F. New terpenes from the Egyptian soft coral Sarcophyton ehrenbergi. Mar. Drugs 2014, 12, 1977-1986. [CrossRef]

5. Eltahawy, N.A.; Ibrahim, A.K.; Radwan, M.M.; ElSohly, M.A.; Hassanean, H.A.; Hassanean, H.A.; Ahmed, S.A. Cytotoxic cembranoids from the Red Sea soft coral, Sarcophyton auritum. Tetrahedron Lett. 2014, 55, 3984-3988. [CrossRef]

6. $\quad$ Lin, W.Y.; Lu, Y.; Su, J.H.; Wen, Z.H.; Dai, C.F.; Kuo, Y.H.; Sheu, J.H. Bioactive cembranoids from the dongsha atoll soft coral Sarcophyton crassocaule. Mar. Drugs 2011, 9, 994-1006. [CrossRef]

7. Lin, W.Y.; Su, J.H.; Lu, Y.; Wen, Z.H.; Dai, C.F.; Kuo, Y.H.; Sheu, J.H. Cytotoxic and anti-inflammatory cembranoids from the Dongsha Atoll soft coral Sarcophyton crassocaule. Bioorg. Med. Chem. 2010, 18, 1936-1941. [CrossRef] 
8. Hassan, H.M.; Rateb, M.E.; Hassan, M.H.; Sayed, A.M.; Shabana, S.; Raslan, M.; Amin, E.; Behery, F.A.; Ahmed, O.M.; Bin Muhsinah, A.; et al. New antiproliferative cembrane diterpenes from the Red Sea Sarcophyton species. Mar. Drugs 2019, 17, 411. [CrossRef]

9. Huang, C.Y.; Tseng, Y.J.; Chokkalingam, U.; Hwang, T.L.; Hsu, C.H.; Dai, C.F.; Sung, P.J.; Sheu, J.H. Bioactive isoprenoid-derived natural products from a Dongsha Atoll soft coral Sinularia erecta. J. Nat. Prod. 2016, 79, 1339-1346. [CrossRef]

10. Tseng, Y.J.; Yang, Y.C.; Wang, S.K.; Duh, C.Y. Numerosol A-D, new cembranoid diterpenes from the soft coral Sinularia numerosa. Mar. Drugs 2014, 12, 3371-3380. [CrossRef]

11. Lillsunde, K.-E.; Festa, C.; Adel, H.; De Marino, S.; Lombardi, V.; Tilvi, S.; Nawrot, D.A.; Zampella, A.; D'Souza, L.; D'Auria, M.V.; et al. Bioactive cembrane derivatives from the Indian Ocean soft coral, Sinularia kavarattiensis. Mar. Drugs 2014, 12, 4045-4068. [CrossRef]

12. Li, G.; Zhang, Y.; Deng, Z.; van Ofwegen, L.; Proksch, P.; Lin, W. Cytotoxic cembranoid diterpenes from a soft coral Sinularia gibberosa. J. Nat. Prod. 2005, 68, 649-652. [CrossRef]

13. Cheng, S.Y.; Wen, Z.H.; Wang, S.K.; Chiou, S.F.; Hsu, C.H.; Dai, C.F.; Chiang, M.Y.; Duh, C.Y. Unprecedented hemiketal cembranolides with anti-inflammatory activity from the soft coral Lobophytum durum. J. Nat. Prod. 2009, 72, 152-155. [CrossRef]

14. Chao, C.H.; Wen, Z.H.; Wu, Y.C.; Yeh, H.C.; Sheu, J.H. Cytotoxic and anti-inflammatory cembranoids from the soft coral Lobophytum crassum. J. Nat. Prod. 2008, 71, 1819-1824. [CrossRef]

15. Lai, K.H.; You, W.J.; Lin, C.C.; El-Shazly, M.; Liao, Z.J.; Su, J.H. Anti-inflammatory cembranoids from the soft coral Lobophytum crassum. Mar. Drugs 2017, 15, 327. [CrossRef] [PubMed]

16. Lin, K.H.; Tseng, Y.J.; Chen, B.W.; Hwang, T.L.; Chen, H.Y.; Dai, C.F.; Sheu, J.H. Tortuosenes A and B, new diterpenoid metabolites from the Formosan soft coral Sarcophyton tortuosum. Org. Lett. 2014, 16, 1314-1317. [CrossRef]

17. Chao, C.H.; Wu, C.Y.; Huang, C.Y.; Wang, H.C.; Dai, C.F.; Wu, Y.C.; Sheu, J.H. Cubitanoids and cembranoids from the soft coral Sinularia nanolobata. Mar. Drugs 2016, 14, 150. [CrossRef]

18. Chen, B.W.; Chao, C.H.; Su, J.H.; Huang, C.Y.; Dai, C.F.; Wen, Z.H.; Sheu, J.H. A novel symmetric sulfur-containing biscembranoid from the Formosan soft coral Sinularia flexibilis. Tetrahedron Lett. 2010, 51, 764-766. [CrossRef]

19. Huang, C.Y.; Sung, P.J.; Uvarani, C.; Su, J.H.; Lu, M.C.; Hwang, T.L.; Dai, C.F.; Wu, S.L.; Sheu, J.H. Glaucumolides A and B, biscembranoids with new structural type from a cultured soft coral Sarcophyton glaucum. Sci. Rep. 2015, 5, 15624. [CrossRef]

20. Jia, R.; Kurtan, T.; Mandi, A.; Yan, X.H.; Zhang, W.; Guo, Y.W. Biscembranoids formed from an alpha, $\beta$-unsaturated gamma-lactone ring as a dienophile: Structure revision and establishment of their absolute configurations using theoretical calculations of electronic circular dichroism spectra. J. Org. Chem. 2013, 78, 3113-3119. [CrossRef]

21. Kusumi, T.; Igari, M.; Ishitsuka, M.O.; Ichikawa, A.; Itezono, Y.; Nakayama, N.; Kakisawa, H. A novel chlorinated biscembranoid from the marine soft coral Sarcophyton glaucum. J. Org. Chem. 1990, 55, 6286-6289. [CrossRef]

22. Tseng, Y.J.; Ahmed, A.F.; Dai, C.F.; Chiang, M.Y.; Sheu, J.H. Sinulochmodins A-C, three novel terpenoids from the soft coral Sinularia lochmodes. Org. Lett. 2005, 7, 3813-3816. [CrossRef] [PubMed]

23. Li, Y.; Pattenden, G. Biomimetic syntheses of ineleganolide and sinulochmodin C from 5-episinuleptolide via sequences of transannular Michael reactions. Tetrahedron 2011, 67, 10045-10052. [CrossRef]

24. Peng, C.C.; Huang, C.Y.; Ahmed, A.F.; Hwang, T.L.; Dai, C.F.; Sheu, J.H. New cembranoids and a iscembranoid peroxide from the soft coral Sarcophyton cherbonnieri. Mar. Drugs 2018, 16, 276. [CrossRef] [PubMed]

25. Sang, V.T.; Dat, T.; Vinh, L.B.; Cuong, L.; Oanh, P.; Ha, H.; Kim, Y.H.; Anh, H.; Yang, S.Y. Coral and coral-associated microorganisms: A prolific source of potential bioactive natural products. Mar. Drugs 2019, 17, 468. [CrossRef] [PubMed]

26. Rodrigues, I.G.; Miguel, M.G.; Mnif, W. A brief review on new naturally occurring cembranoid diterpene derivatives from the soft corals of the genera Sarcophyton, Sinularia, and Lobophytum since 2016. Molecules 2019, 24, 781. [CrossRef] [PubMed]

27. Elkhawas, Y.A.; Elissawy, A.M.; Elnaggar, M.S.; Mostafa, N.M.; Al-Sayed, E.; Bishr, M.M.; Singab, A.N.B.; Salama, O.M. Chemical diversity in species belonging to soft coral genus Sacrophyton and its impact on biological activity: A review. Mar. Drugs 2020, 18, 41. [CrossRef] 
28. Maloney, K.N.; Botts, R.T.; Davis, T.S.; Okada, B.K.; Maloney, E.M.; Leber, C.A.; Alvarado, O.; Brayton, C.; Caraballo-Rodríguez, A.M.; Chari, J.V.; et al. Cryptic species account for the seemingly idiosyncratic secondary metabolism of Sarcophyton glaucum specimens collected in Palau. J. Nat. Prod. 2020, 83, 693-705. [CrossRef]

29. Xi, Z.; Bie, W.; Chen, W.; Liu, D.; van Ofwegen, L.; Proksch, P.; Lin, W. Sarcophyolides B-E, new cembranoids from the soft coral Sarcophyton elegans. Mar. Drugs 2013, 11, 3186-3196. [CrossRef]

30. Kusumi, T.; Yamada, K.; Ishitsuka, M.O.; Fujita, Y.; Kakisawa, H. New cembranoids from the Okinawan soft coral Sinularia mayi. Chem. Lett. 1990, 19, 1315-1318. [CrossRef]

31. Hwang, T.L.; Su, Y.C.; Chang, H.L.; Leu, Y.L.; Chung, P.J.; Kuo, L.M.; Chang, Y.J. Suppression of superoxide anion and elastase release by C18 unsaturated fatty acids in human neutrophils. J. Lipid Res. 2009, 50, 1395-1408. [CrossRef] [PubMed]

32. Yang, S.C.; Chung, P.J.; Ho, C.M.; Kuo, C.Y.; Hung, M.F.; Huang, Y.T.; Chang, W.Y.; Chang, Y.W.; Chan, K.H.; Hwang, T.L. Propofol inhibits superoxide production, elastase release, and chemotaxis in formyl peptide-activated human neutrophils by blocking formyl peptide receptor 1. J. Immunol. 2013, 190, 6511-6519. [CrossRef] [PubMed]

33. Yu, H.P.; Hsieh, P.W.; Chang, Y.J.; Chung, P.J.; Kuo, L.M.; Hwang, T.L. 2-(2-Fluorobenzamido) benzoate ethyl ester (EFB-1) inhibits superoxide production by human neutrophils and attenuates hemorrhagic shock-induced organ dysfunction in rats. Free Radic. Biol. Med. 2011, 50, 1737-1748. [CrossRef] [PubMed]

34. Wei, W.-C.; Sung, P.-J.; Duh, C.-Y.; Chen, B.-W.; Sheu, J.-H.; Yang, N.-S. Anti-inflammatory activities of natural products isolated from soft corals of Taiwan between 2008 and 2012. Mar. Drugs 2013, 11, 4083-4126. [CrossRef] [PubMed]

35. Ahmad, B.; Shah, M.; Choi, S. Oceans as a source of immunotherapy. Mar. Drugs 2019, 17, 282. [CrossRef] [PubMed]

Publisher's Note: MDPI stays neutral with regard to jurisdictional claims in published maps and institutional affiliations.

(C) 2020 by the authors. Licensee MDPI, Basel, Switzerland. This article is an open access article distributed under the terms and conditions of the Creative Commons Attribution (CC BY) license (http://creativecommons.org/licenses/by/4.0/). 